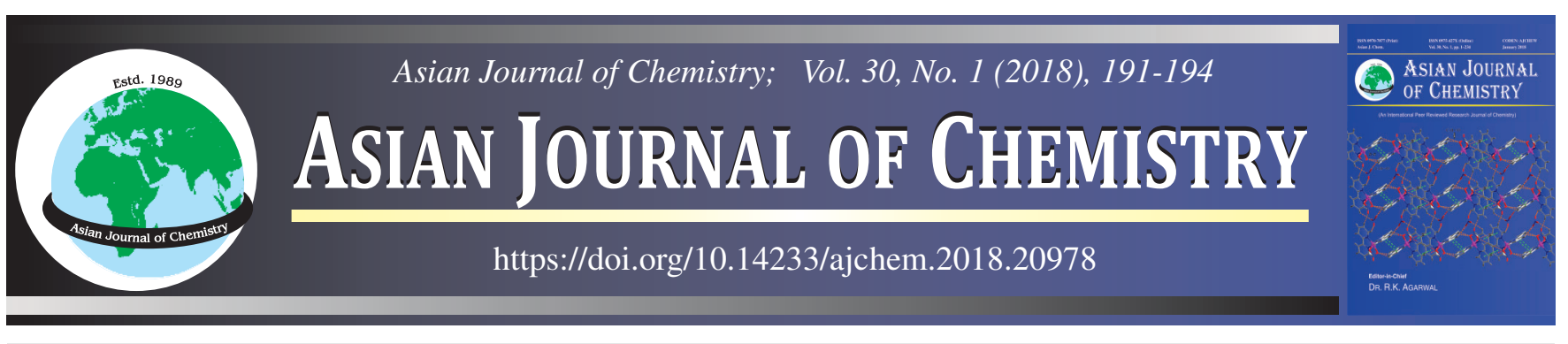

\title{
Synthesis, Characterization and Biological Applications of Random Aliphatic Copolythioesters Using 3,3'-Thiodipropionic Acid
}

\author{
KosinAPOGU SUdHAKAR ${ }^{*}$ and R. NANTHINI
}

Post Graduate \& Research Department of Chemistry, Pachaiyappa's College, Chennai-600 030, India

*Corresponding author: E-mail: sudhak16chem@gmail.com

Received: 16 August 2017;

Accepted: 11 October 2017;

Published online: 30 November 2017;

AJC-18674

\begin{abstract}
The aliphatic random copolyester polycyclohexylthiodipropionate-co-cyclohexyldecanedioate (PCTCD) containing sulphur atom in the main chain was synthesized by mixing 3,3'-thiodipropionic acid, decanedioic acid and 1,4-cyclohexanediol monomers with titanium tetra isopropoxide catalyst using direct melt polycondensation method. The different physical properties of copolyester such as inherent viscosity, solubility, differential scanning colorimetry and X-ray diffraction technique was investigated. The chemical structure of the copolyester was investigated by FTIR, ${ }^{1} \mathrm{H}$ NMR and ${ }^{13} \mathrm{C}$ NMR spectroscopy. The synthesized compounds were tested for human pathogenic bacteria using well diffusion method, in vitro cytotoxicity against normal (Vero cell line) and cancer ( $\mathrm{A}_{549}$ lung cancer cell line) by MTT assay. Also in vitro antioxidant property of copolymer was studied.
\end{abstract}

Keywords: Polycyclohexylthiodipropionate-co-cyclohexyldecanedioate, 3,3'-Thiodipropionic acid, Decanedioic acid, 1,4-Cyclohexanediol.

\section{INTRODUCTION}

In early studies, low molecular weight aliphatic polyesters are used as plasticizers, stabilizers and very good antioxidants like PBA, PVC etc., The only other sulfur-containing biopolymers known are proteins, some complex polysaccharides and recently described PHAs allow various applications in medicine, pharmacy, agriculture, packaging and food industry, as active agents or as coatings or carriers [1]. Hydroxyl terminated aliphatic and aromatic thiopolyesters are used as polyol components in the synthesis of high elasticity polyurethane elastomers [2]. Poly(3HB-co-3MP) is the first biopolymer which are designated as polythioesters contains sulfur in the polymer backbone [3]. Linear copolymeric polyesters i.e., poly(3,3'-thiodipropionic acid-co-1,6-hexanediol) and poly (3,3'-thiodipropionic acid-co-1,12-dodecanediol) by esterification of an equimolar mixture of 3,3'-thiodipropionic acid and 1,6-hexanediol or 1,12-dodecanediol catalyzed by immobilized lipase B from Candida antarctica (Novozym 435) were extracted from the reaction mixtures using tetra-hydrofuran and precipitated from tetrahydrofuraniso-hexane [4]. In the present work, we have synthesized a low molecular weight linear copolythioesters by using special monomer 3,3'-thiodipropionic acid, which has many applications in food, medicine, paint, plastic and pharmaceutical industries.

\section{EXPERIMENTAL}

3,3'-Thiodipropionic acid, decanedioic acid and 1,4cyclohexanediol was purchased from Sigma Aldrich. The catalyst titanium tetra isopropoxide was purchased from Lancaster. All other chemicals and solvents (AR Grade) were purchased from Sigma Aldrich, Mumbai. FT-IR spectra were recorded on Perkin Elmer 883 spectrophotometer. ${ }^{1} \mathrm{H}$ NMR and ${ }^{13} \mathrm{C}$ NMR spectra for copolyester was recorded on a Bruker $400 \mathrm{MHz}$ and Bruker $100 \mathrm{MHz}$ spectrometer respectively using $\mathrm{CDCl}_{3}$ as a solvent. DSC thermogram was recorded on DSC Q200 V23.10 Build 79 differential scanning calorimeter. Bruker $\mathrm{B} 8$ wide angle $\mathrm{XRD}$ with $\mathrm{Cu} / 30 \mathrm{kv} / 15 \mathrm{~mA}$ was used for assessing crystalline or amorphous nature of copolymer. Biological application of PDTDD carried out such as in vitro antioxidant activity by dot blot assay [5], in vitro antioxidant activity with spectrophotometer at 15.6, 31.2, 62.5, 125, 250, 500 and 1000 $\mu \mathrm{g} / \mathrm{mL}$ in vitro antibacterial activity well diffusion method [6] with 250,500 and $1000 \mu \mathrm{g} / \mathrm{mL}$ against the human pathogens such as Escherichia coli, Klebsiella pneumoniae, Bacillus subtilis, Staphylococcus aureus and in vitro cytotoxicity of vero (normal) cell line and lung cancer $\left(\mathrm{A}_{549}\right)$ line with various concentrations of PCTCD like 7.8, 15.6, 31.2, 62.5, 125, 250, 500 and $1000 \mu \mathrm{g} / \mathrm{mL}$ [7].

Synthesis of copolyester: A mixture of 3,3'-thiodipropionic acid $(0.01 \mathrm{~mol})$, decanedioic acid $(0.01 \mathrm{~mol})$ and $1,4-$ 


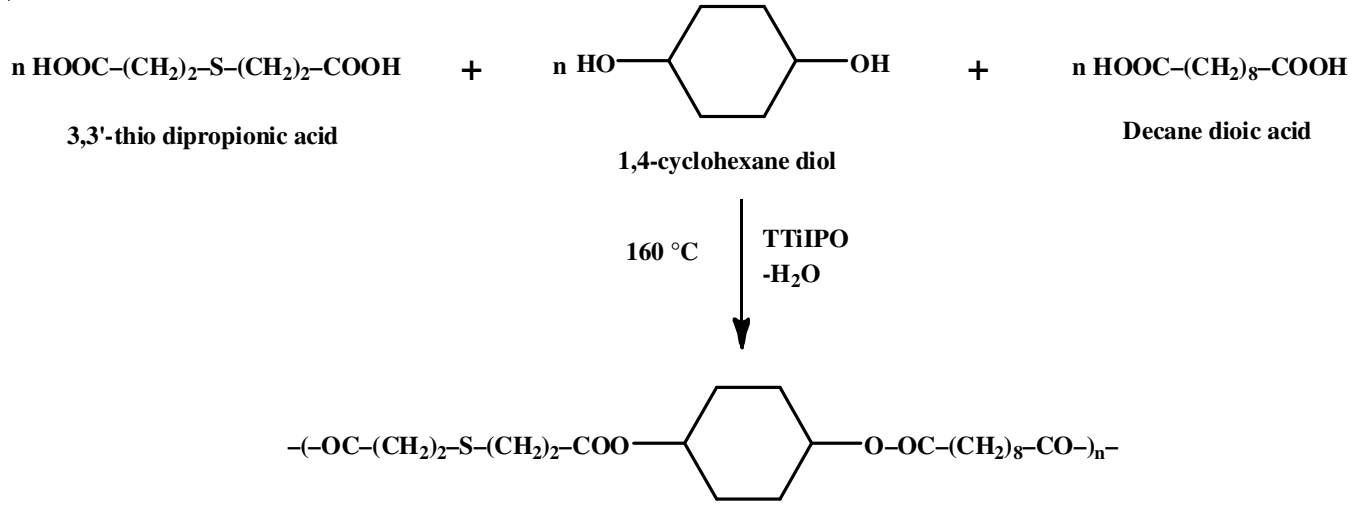

Poly cyclohexylthiodipropionate-co-cyclohexyldecanediolate

Scheme-I: Synthesis of copolyester

cyclohexanediol $(0.02 \mathrm{~mol})$ was taken in a three-neck round bottom flask. One of the left inlet of round bottom flask connected to nitrogen cylinder, right inlet with stopper and middle inlet with $\mathrm{CaCl}_{2}$ guard tube. The set up is kept in oil bath and heated at its melting point. After the complete melt of mixture $0.8 \mathrm{~mL}$ of titanium tetraisopropoxide catalyst is added and kept for $1 \mathrm{~h}$. Later the temperature is increased by $25^{\circ} \mathrm{C}$ and maintained for $2 \mathrm{~h}$. At $0.5 \mathrm{~h}$ interval the recrystallization is checked with the reaction sample. The obtained crude copolymer sample is dissolved in chloroform/THF and poured into ice-cold methanol, a pure copolymer PCTCD is reprecipitated as given in Scheme-I.

\section{RESULTS AND DISCUSSION}

Characterization of physical parameters: Solubilities of the synthesized copolymer were determined in various solvents. It has been found that the copolymer is soluble in chloroform, dimethyl formamide, THF and DMSO. Inherent viscosity of the copolymer PCTCD is 0.796 and was determined by flow times of solvent and one percent solution of the copolymer dissolved in chloroform and taken in Ubbelohde viscometer. The DSC thermogram of the colpolymer PCTCD (Fig. 1) shows glass transition temperature $\left(\mathrm{T}_{\mathrm{g}}\right)$ at $-50{ }^{\circ} \mathrm{C}$ and melting temperature $\left(\mathrm{T}_{\mathrm{m}}\right)$ at $72.43{ }^{\circ} \mathrm{C}$ which signifies the copolymer has low molecular weight and may be used as plasticizers, stabilizers and very good antioxidants like PBA, PVC etc., Wide XRD of the synthesized copolymer in Fig. 2 gives the value of $2 \theta\left(^{\circ}\right)=21-23^{\circ}$ which confirms that the polymer is amorphous in nature.

Structural elucidation: The FT-IR spectrum (Fig. 3) of the synthesized copolyester PCTCD showed characteristic absorption band for ester carbonyl stretching at $1730 \mathrm{~cm}^{-1}$. Also the polymer was observed peaks at 640, 1250, 2910 and $1460 \mathrm{~cm}^{-1}$ due to $\mathrm{C}-\mathrm{S}$ stretching, C-O-C asymmetric stretching, aliphatic $\mathrm{C}-\mathrm{H}$ stretching of methylene group and aliphatic $\mathrm{C}-\mathrm{C}$ stretching respectively. The $\mathrm{C}-\mathrm{C}$ stretching vibrations of the cyclohexyl ester give rise to absorption band at $1090 \mathrm{~cm}^{-1}$. A new ester bond that was formed during polycondensation can be revealed from the report.

${ }^{1} \mathrm{H}$ NMR spectrum of the copolyester is shown in Fig. 4. The peaks at $\delta=1.533-1.698 \mathrm{ppm}$ and $\delta=1.717-1.894 \mathrm{ppm}$ was due to methylene protons of copolyester and cyclohexane ring respectively. In addition the peak at $\delta=2.186-2.822 \mathrm{ppm}$

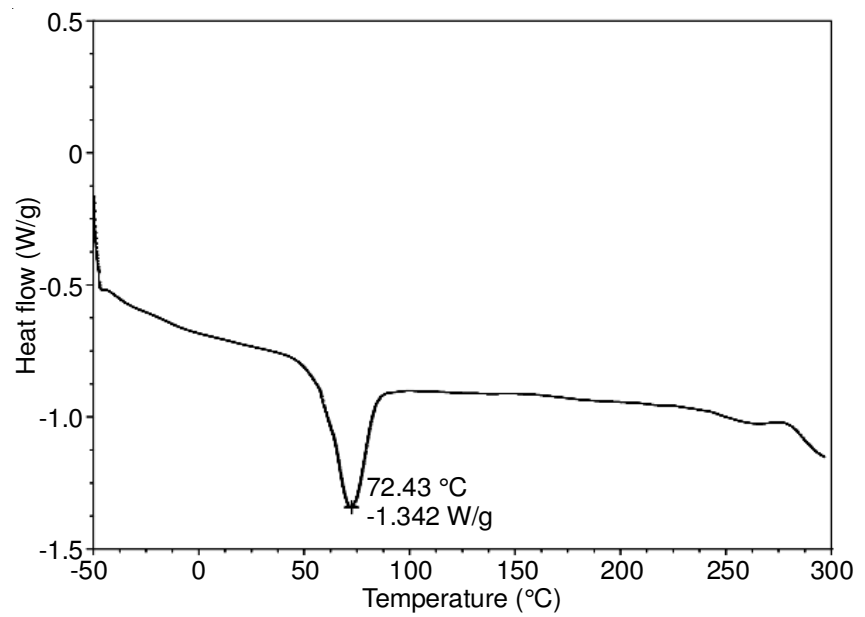

Fig. 1. DSC thermogram of the copolymer
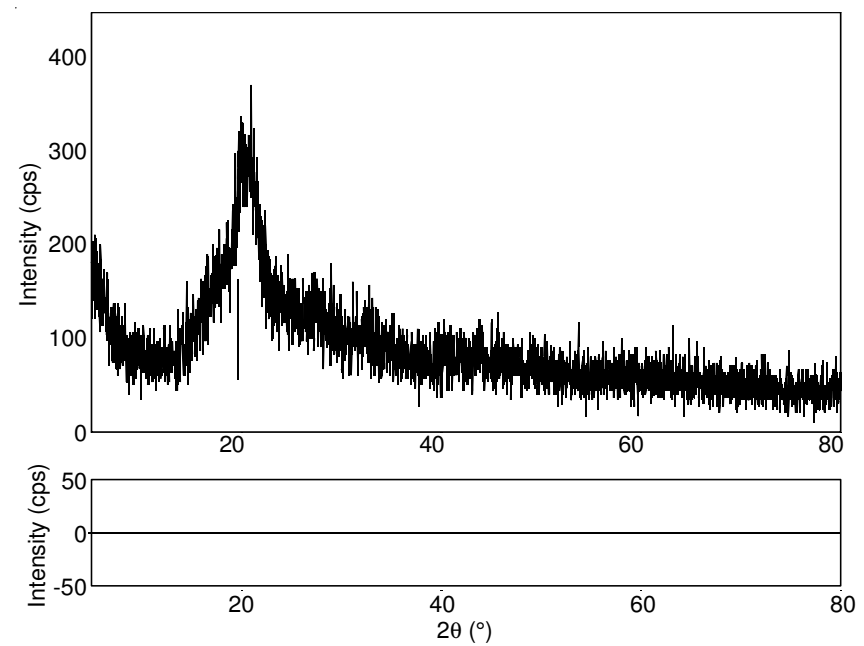

Fig. 2. Wide XRD of the copolymer

was attributed to- $\mathrm{CH}_{2}-\mathrm{CO}$-protons, the signal $\delta=2.709-2.771$ was due to $\mathrm{C}-\mathrm{CH}_{2}-\mathrm{S}$ protons wile $\delta=4.746-4.779 \mathrm{ppm}$ is due to $\mathrm{C}-\mathrm{CH}_{2}-\mathrm{O}$ protons.

${ }^{13} \mathrm{C}$ NMR spectrum of the copolyester (Fig. 5) shows the signals at $\delta=24.49-25.44 \mathrm{ppm}$ was attributed to methylene protons of copolyester and at $\delta=27.33-27.94 \mathrm{ppm}$ due to methylene protons of cyclohexane ring respectively. In addition the peaks at $\delta=28.03-35.03$ ppm and $\delta=69.42-71.38$ was attributed to- $\mathrm{CH}_{2}-\mathrm{S}$-and- $\mathrm{CH}_{2}$-O-respectively, while $\delta=171.17$ and $173.22 \mathrm{ppm}$ is due to ester groups. 


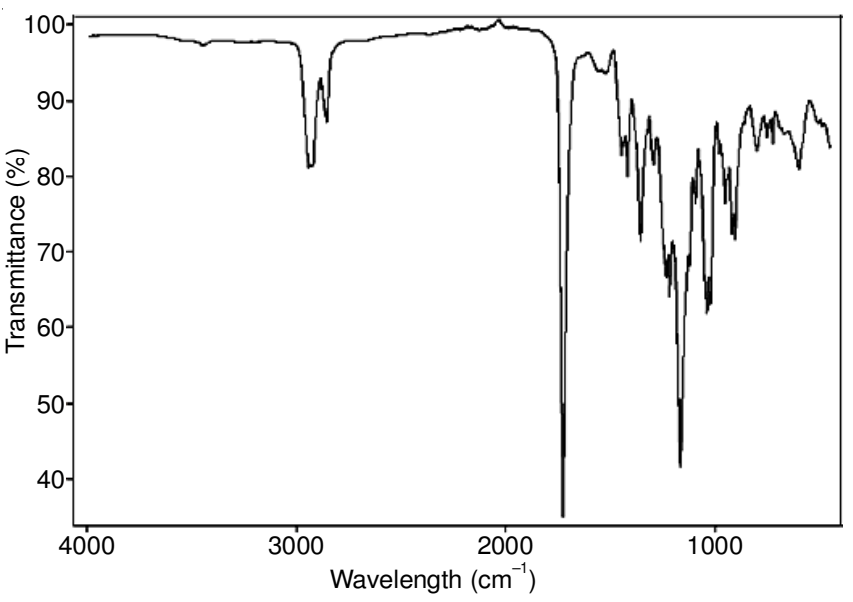

Fig. 3. FT-IR spectrum of the copolyester

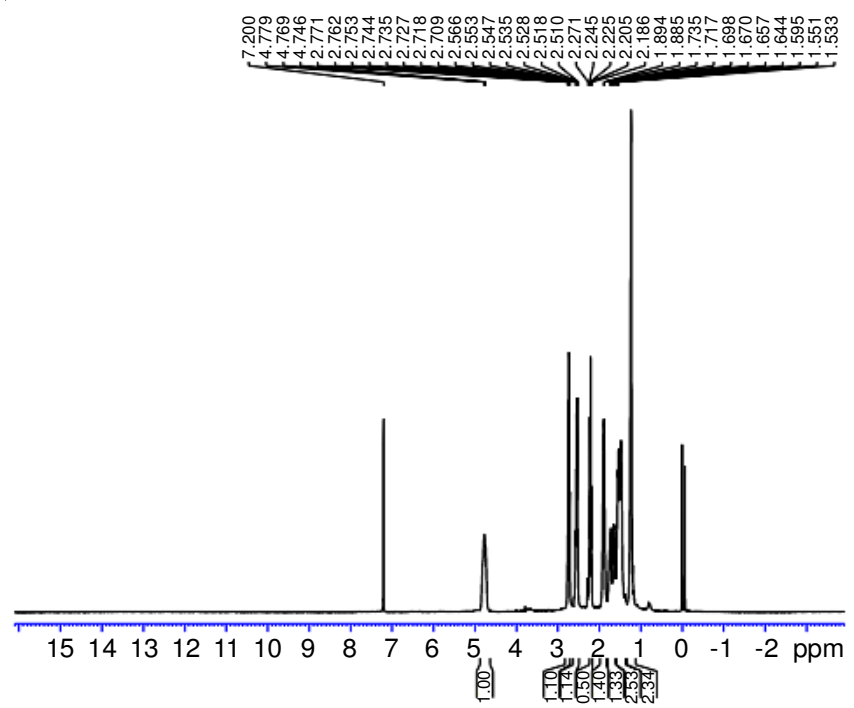

Fig. $4 .{ }^{1} \mathrm{H}$ NMR spectrum of the copolyester

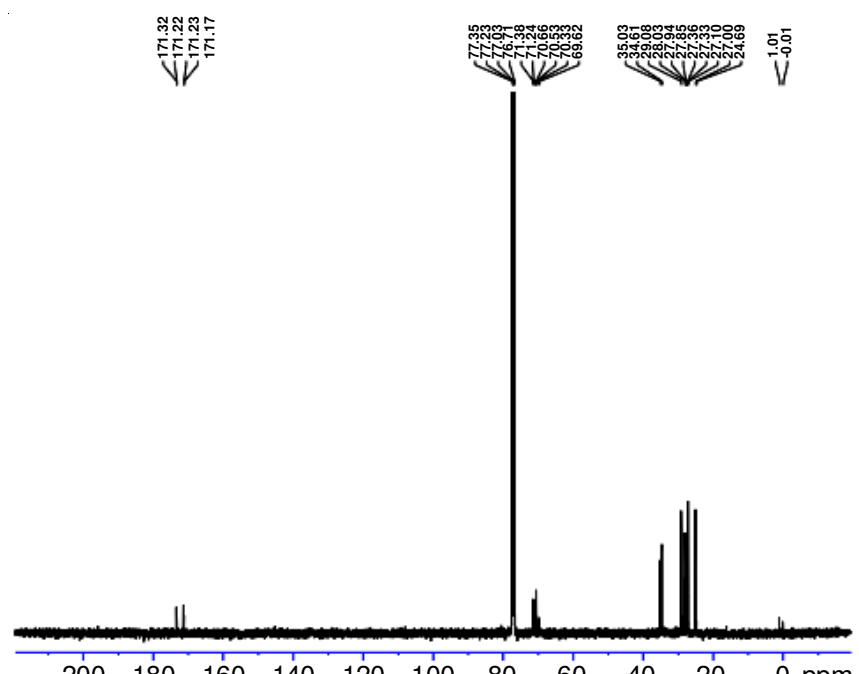

Fig. $5 .{ }^{13} \mathrm{C}$ NMR spectrum of the copolyester

Biological studies: Synthesized compounds were tested for cytotoxicity on Vero (normal) cell line and lung cancer (A549) line with various concentrations of PCTCD like 7.8, $15.6,31.2,62.5,125,250,500$ and $1000 \mu \mathrm{g} / \mathrm{mL}$. The compound showed different ranges of viability, cell shrinkage in dose dependent manner (Tables 1-3), observed under stereomicroscope. At the maximum concentration of PCTCD $(1000 \mu \mathrm{g} /$ $\mathrm{mL}$ ), the cell viability were $51.37 \%$ for Vero cell line and $17.01 \%$ for lung cancer A549 cell line. The copolymer PCTCD showed more toxic on lung cancer cell than normal Vero cell line. Fifty percent death was calculated at the concentration of $973.33 \mu \mathrm{g} / \mathrm{mL}$ Vero cell and $55.77 \mu \mathrm{g} / \mathrm{mL}$ lung cancer cell. In vitro antioxidant property of PCTCD copolymer showed radical scavenging activity on thin layer chromatography purple colour of DPPH radical turned into yellow which confirms the polymer has antioxidant activity by Dot-Blot assay (Tables 4 and 5). The maximum percentages of inhibition activity of compound PCTCD is $63.64 \%$ at the concentration of $1000 \mu \mathrm{g} /$ $\mathrm{mL}$, whereas standard showed maximum percentage of Inhibition activity $75.85 \%$ (quercetin) at the concentration of $10 \mu \mathrm{g} / \mathrm{mL}$. $\mathrm{IC}_{50}(\mu \mathrm{g} / \mathrm{mL})$ value for PCTCD is 425.33 , while for standard quercetin it was $(6.59 \mu \mathrm{g} / \mathrm{mL})$. In vitro antimicrobial activities exhibited 10 to $15 \mathrm{~mm}$ and inhibition percentage 11.22 to 16.67 $\%$ against the pathogens (Table-6) by well diffusion method.

\begin{tabular}{cc} 
TABLE-1 \\
CYTOTOXICITY EFFECT OF SYNTHESIZED COMPOUND \\
PCTCD ON VERO (NORMAL) CELL LINE \\
\hline Concentration of compounds $(\mu \mathrm{g} / \mathrm{mL})$ & Cell viability $(\%)$ \\
\hline 1000 & 51.37 \\
500 & 58.64 \\
250 & 63.41 \\
125 & 69.06 \\
62.5 & 74.71 \\
31.2 & 80.49 \\
15.6 & 88.83 \\
7.8 & 92.60 \\
Cell control & 100 \\
$\mathrm{IC}_{50}$ value $(\mu \mathrm{g} / \mathrm{mL})$ & 973.330 \\
\hline
\end{tabular}

\begin{tabular}{|c|c|c|c|}
\hline \multicolumn{4}{|c|}{$\begin{array}{c}\text { TABLE-2 } \\
\text { CYTOTOXICITY OF SYNTHESIZED COMPOUNDS } \\
\text { PCTCD AGAINST LUNG CANCER }\left(\mathrm{A}_{549}\right) \text { CELL LINE }\end{array}$} \\
\hline \multicolumn{2}{|c|}{ Concentration of compounds ( $\mu \mathrm{g} / \mathrm{mL})$} & \multicolumn{2}{|c|}{ Cell viability $(\%)$} \\
\hline \multicolumn{2}{|c|}{1000} & \multicolumn{2}{|c|}{17.01} \\
\hline \multicolumn{2}{|c|}{500} & \multicolumn{2}{|c|}{30.22} \\
\hline \multicolumn{2}{|c|}{250} & \multicolumn{2}{|c|}{38.78} \\
\hline \multicolumn{2}{|c|}{125} & \multicolumn{2}{|c|}{48.30} \\
\hline \multicolumn{2}{|c|}{62.5} & \multicolumn{2}{|c|}{56.03} \\
\hline \multicolumn{2}{|c|}{31.2} & \multicolumn{2}{|c|}{67.63} \\
\hline \multicolumn{2}{|c|}{15.6} & \multicolumn{2}{|c|}{75.13} \\
\hline \multicolumn{2}{|c|}{7.8} & \multicolumn{2}{|c|}{86.31} \\
\hline \multirow{2}{*}{\multicolumn{2}{|c|}{$\begin{array}{c}\text { Cell control } \\
\mathrm{IC}_{50} \text { value }(\mu \mathrm{g} / \mathrm{mL})\end{array}$}} & \multicolumn{2}{|c|}{100} \\
\hline & & \multicolumn{2}{|c|}{55.77} \\
\hline \multicolumn{4}{|c|}{$\begin{array}{c}\text { TABLE-3 } \\
\text { ANTICANCER EFFECT OF PCTCD ON VERO CELL LINE }\end{array}$} \\
\hline $\begin{array}{c}\text { Concentration } \\
(\mu \mathrm{g} / \mathrm{mL})\end{array}$ & Dilutions & $\begin{array}{l}\text { Absorbance } \\
\text { (O.D) }\end{array}$ & $\begin{array}{c}\text { Cell viability } \\
(\%)\end{array}$ \\
\hline 1000 & Neat & 0.764 & 51.37 \\
\hline 500 & $1: 1$ & 0.872 & 58.64 \\
\hline 250 & $1: 2$ & 0.943 & 63.41 \\
\hline 125 & $1: 4$ & 1.027 & 69.06 \\
\hline 62.5 & $1: 8$ & 1.111 & 74.71 \\
\hline 31.2 & $1: 16$ & 1.197 & 80.49 \\
\hline 15.6 & $1: 32$ & 1.321 & 88.83 \\
\hline 7.8 & $1: 64$ & 1.377 & 92.60 \\
\hline Cell control & - & 1.487 & 100 \\
\hline
\end{tabular}




\begin{tabular}{|c|c|c|c|}
\hline \multicolumn{4}{|c|}{$\begin{array}{c}\text { TABLE-6 } \\
\text { ANTIMICROBIAL ACTIVITY OF COMPOUND PCTCD AGAINST HUMAN PATHOGENS BY WELL DIFFUSION METHOD }\end{array}$} \\
\hline \multirow{2}{*}{ Human pathogens } & \multirow{2}{*}{ Concentration $(\mu \mathrm{g})$} & \multicolumn{2}{|c|}{ Zone of inhibition (\%) } \\
\hline & & PCTCD & Kannamycin $(30 \mu \mathrm{g})$ \\
\hline \multirow{3}{*}{ Escherichia coli } & 1000 & $15 \pm 1.05(16.67 \pm 1.17)$ & \multirow{3}{*}{$26.33 \pm 1.52(29.25 \pm 1.38)$} \\
\hline & 500 & $13 \pm 0.91(14.44 \pm 1.0)$ & \\
\hline & 250 & $10 \pm 0.7(11.11 \pm 0.7)$ & \\
\hline \multirow{3}{*}{ Klebsiella pneumoniae } & 1000 & $13 \pm 0.91(14.44 \pm 1.0)$ & \multirow{3}{*}{$30.67 \pm 1.52(34.07 \pm 1.38)$} \\
\hline & 500 & $12 \pm 0.84(13.33 \pm 0.9)$ & \\
\hline & 250 & $10 \pm 0.7(11.11 \pm 0.7)$ & \\
\hline \multirow{3}{*}{ Bacillus subtilis } & 1000 & $12 \pm 0.84(13.33 \pm 0.93$ & \multirow{3}{*}{$27.00 \pm 1.00(30.00 \pm 0.90)$} \\
\hline & 500 & $10 \pm 0.77(11.11 \pm 0.7)$ & \\
\hline & 250 & - & \\
\hline \multirow{3}{*}{ Staphylococcus aureus } & 1000 & $14 \pm 0.98(15.55 \pm 1.08)$ & \multirow{3}{*}{$26.00 \pm 1.00(29.25 \pm 0.52)$} \\
\hline & 500 & $11 \pm 0.77(12.22 \pm 0.85)$ & \\
\hline & 250 & - & \\
\hline
\end{tabular}

\begin{tabular}{cc} 
TABLE-4 \\
In vitro DPPH ACTIVITIES OF COMPOUNDS PCTCD \\
\hline Concentration of compounds $(\mu \mathrm{g} / \mathrm{mL})$ & PCTCD inhibition $(\%)$ \\
\hline 1000 & $63.64 \pm 4.45$ \\
500 & $58.75 \pm 4.11$ \\
250 & $44.21 \pm 3.09$ \\
125 & $40.94 \pm 2.86$ \\
62.5 & $33.97 \pm 2.37$ \\
31.25 & $20.77 \pm 1.45$ \\
15.62 & $14.24 \pm 0.99$ \\
$\mathrm{IC}_{50}(\mu \mathrm{g} / \mathrm{mL})$ & 425.53 \\
\hline
\end{tabular}

All values are mean values of triplicates (mean \pm standard deviation).

\begin{tabular}{cc} 
TABLE-5 \\
In vitro DPPH ANTIOXIDANT ACTIVITIES \\
OF STANDARD (QUERCETIN) \\
\hline Concentration of compounds $(\mu \mathrm{g} / \mathrm{mL})$ & Inhibition $(\%)$ \\
\hline 1.0 & $7.58 \pm 0.53$ \\
2.0 & $15.17 \pm 1.06$ \\
3.0 & $22.75 \pm 1.59$ \\
4.0 & $30.34 \pm 2.12$ \\
5.0 & $37.92 \pm 2.65$ \\
6.0 & $45.51 \pm 3.18$ \\
7.0 & $53.09 \pm 3.71$ \\
8.0 & $60.68 \pm 4.24$ \\
10.0 & $75.85 \pm 5.30$ \\
$\mathrm{IC}_{50}(\mu \mathrm{g} / \mathrm{mL})$ & 6.59 \\
\hline
\end{tabular}

All values are mean values of triplicates (mean \pm standard deviation).

\section{ACKNOWLEDGEMENTS}

The authors grateful to The Principal and Head of Department, Pachaiyappa's College, Chennai, India for laboratory facility, Central Leather Research Institute (CLRI) and VIT-Vellore for their instrumentation facilities.

\section{REFERENCES}

1. A. Steinbuchel, T. Lutke-Eversloh and C. Ewering, Sulfur Containing Polyhydroxyalkanoate Compositions and Method of Production, US Patent 6495152 B2 (2002).

2. H.F. Mark, Encylopedia of Polymer Science and Technology Concise, John Wiley \& Sons, edn 3, pp. 1169 (2013)

3. A. Steinbüchel, H. Luftmann, K. Bergander and T. Lütke-Eversloh, Microbiology, 147, 11 (2001);

https://doi.org/10.1099/00221287-147-1-11.

4. E. Fehling, E. Klein, K. Vosmann, K. Bergander and N. Weber, Biotechnol. Bioeng., 99, 1074 (2008); https://doi.org/10.1002/bit.21704.

5. M.S. Blois, Nature, 181, 1199 (1958); https://doi.org/10.1038/1811199a0.

6. C. Perez, M. Pauli and P. Bazerque, Acta Biol. Med. Exp., 15, 113 (1958).

7. T. Mosmann, J. Immunol. Methods, 65, 55 (1983); https://doi.org/10.1016/0022-1759(83)90303-4. 